\title{
Análise de Impacto de Curto Prazo da Política Fiscal: Redução do IPI no período 2008-2009*
}

\section{Impact Analysis of Short-Term Fiscal Policy: IPI reduction 2008-2009}

\author{
Carlândia Brito Santos Fernandes** \\ Joaquim José Martins Guilhoto* * *
}

\begin{abstract}
Resumo: O objetivo deste artigo é investigar os efeitos de curto prazo na economia brasileira da redução do IPI no setor automobilístico entre 2008 e 2009. Utilizando o ferramental de matriz insumo-produto, a importância do setor automobilístico fica evidente por meio dos resultados dos índices de ligação e dos multiplicadores de emprego. Dada a hipótese de que a desoneração do IPI gerou um aumento na demanda do setor de $13,4 \%$ durante o ano de 2009, os resultados da análise de impacto indicam que os efeitos sobre a economia brasileira seriam de um aumento de mais de $\mathrm{R} \$ 32$ bilhões na produção bruta, quase $\mathrm{R} \$ 10$ bilhões no PIB e mais de 211 mil empregos. Assim, os resultados geram uma única e abrangente predição: as respostas de curto prazo à política fiscal contracíclica operam através da demanda agregada, ou seja, trata-se de uma resposta do tipo keynesiana, estabilizadora, que contribui para amenizar os impactos negativos da crise financeira na economia brasileira.
\end{abstract}

Palavras-chave: Política fiscal. Setor automobilístico. Insumo-produto.

Abstract: The aim of this paper is to investigate the short-term effects on the Brazilian economy of IPI reduction in the automotive sector between 2008 and 2009. Using the input-output matrix analysis, the importance of the automotive sector is evident by the results of the linkages indices and employment multipliers. Considering the hypothesis that the IPI tax generated an increase in demand in the sector of $13.4 \%$ during the year 2009, the results of the impact analysis indicate that the effects on the Brazilian economy would be an increase of more than $\mathrm{R} \$ 32$ billions in gross production, around $\mathrm{R} \$ 10$ billions in GDP and more than 211 thousand jobs. Thus, the results generate an ample prediction: the short-term responses to countercyclical fiscal policy operated by aggregate demand, is a Keynesian response, stabilize, which helped to mitigate the negative impacts of the financial crisis in the Brazilian economy.

Keywords: Fiscal policy. Automotive sector. Input-output.

* $\quad$ Artigo desenvolvido com apoio da Fundação de Amparo à Pesquisa do Estado de São Paulo (Fapesp), processo $n^{\circ}$ 2012/04600-0. As opiniões, hipóteses e conclusões ou recomendações expressas neste material são de responsabilidade dos autores e não necessariamente refletem a visão da Fapesp.

* $\quad$ Doutoranda em Economia do Desenvolvimento pela Faculdade de Economia e Administração (FEA) da Universidade de São Paulo (USP). E-mail: carlandia@gmail.com

*** Professor titular da Faculdade de Economia e Administração (FEA) da Universidade de São Paulo (USP). Adjunct professor do Regional Economics Applications Laboratory (Real) da University of Illinois. Pesquisador do CNPq. E-mail: guilhoto@usp.br 


\section{Introdução}

A partir da crise financeira de 2008, o papel contracíclico, estabilizador, da política fiscal tem recebido mais atenção. Especialmente nos países em desenvolvimento ampliou-se o interesse pela política fiscal, sendo que no ápice da crise muitos desses países foram capazes de ampliar seus gastos, apesar da redução das receitas fiscais, em contraste a crises anteriores, quando os países, frequentemente, cortavam gastos (BRAHMBHATT; CANUTO, 2012). De acordo com a literatura, na qual se destacam Gavin e Perotti (1997), Kaminsky, Reinhart e Vegh (2004), Talvi e Vegh (2005), Mello e Moccero (2006), Blanco e Herrera (2006) e Rocha (2009), é convencional os países em desenvolvimento apresentarem padrão de política fiscal pró-cíclico, isto é, desestabilizador, de ampliação dos estímulos fiscais durante períodos de expansão do nível de atividade, e o oposto durante períodos de redução.

Frankel, Végh e Vuletin (2013), ao utilizarem como base de análise o comportamento dos gastos do governo em relação ao ciclo de negócios, destacam que alguns países, como Brasil e Chile, apresentaram uma mudança no padrão da política fiscal: a proporção de países em desenvolvimento de política fiscal contracíclica aumentou de menos de 10\%, entre 1960 e 1999, para mais de 30\%, entre 2000 e 2009, embora os autores mantenham a posição de que, no geral, países em desenvolvimento são de padrão fiscal pró-cíclico, enquanto os desenvolvidos são contracíclico. Essa constatação vai de encontro à posição de política fiscal adotada por muitos países em desenvolvimento no ápice da crise.

Os primeiros reflexos da crise financeira mundial, do final de 2008 , foram de intensa restrição do crédito ofertado por instituições estrangeiras, principalmente para as atividades de exportação. Instituições financeiras domésticas elevaram o spread de suas operações correntes no país, limitando ainda mais a oferta de crédito. Paralelamente, grandes empresas do setor produtivo brasileiro revelaram perdas significativas, em função de investirem parte considerável dos ganhos acumulados em atividades financeiras. Consequentemente, a economia brasileira foi atingida por uma crise de confiança por parte de empresários e trabalhadores, isto é, uma crise de contenção de gastos de investimento e consumo (SICSÚ, 2009).

O setor industrial rapidamente refletiu os efeitos da crise. No final de 2008 houve uma retração na produção industrial de aproximadamente $12 \%$ no mês de dezembro em relação ao mês anterior, conforme apresentado no Gráfico 1. Contribuiu para esse resultado a indústria automobilística, principalmente porque sua produção registrou uma redução de quase 39\% no mesmo período (IBGE, 2008). A indústria automobilística foi um dos setores mais afetados pela redução da demanda doméstica, pois, assim como o setor de bens de capital, depende 
diretamente de financiamentos, e estes estavam comprometidos com a escassez de crédito (ASSUNÇÃO, 2011).

Gráfico 1 - Produção da indústria geral e de veículos automotores de janeiro de 2007 a dezembro de $2009^{1}$

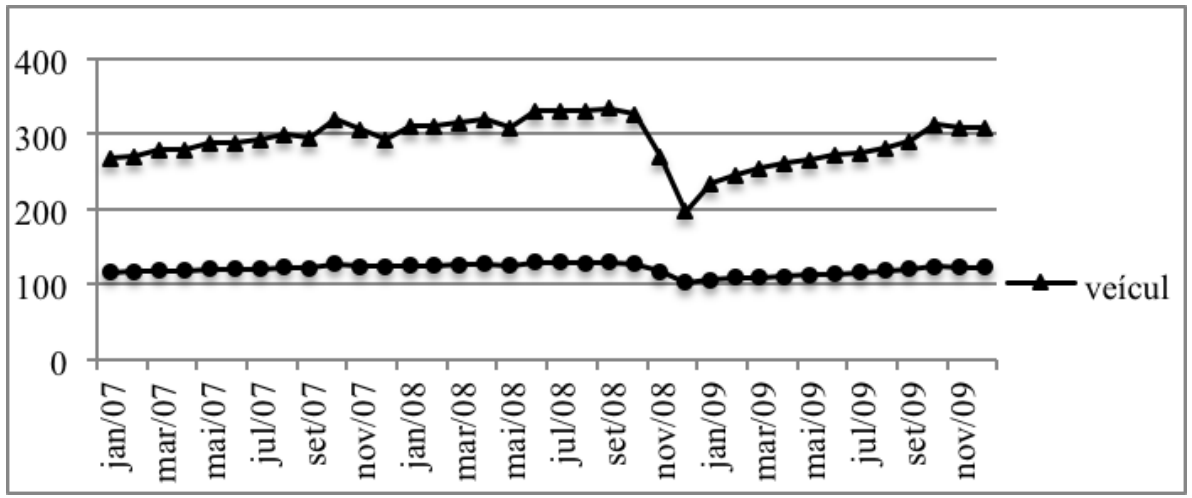

Fonte: Elaboração própria a partir de dados de IBGE (2008).

O governo brasileiro adotou medidas de política fiscal anticíclica, dentre elas destacam-se as reduções nas alíquotas do imposto sobre produtos industrializados (IPI) para automóveis, as quais serão base de análise deste trabalho. Em resumo, as reduções foram de $100 \%$ para carros até 1000 cilindradas, 50\% para carros entre 1000 e no máximo 3000 cilindradas e de $75 \%$ para camionetas e furgões. ${ }^{2}$ É importante destacar o foco das medidas sobre os veículos populares, pois, de acordo com Moraes e Silveira (2005), esses tipos de veículos possuem elasticidade-preço da demanda superior à unidade, caracterizando-a como razoavelmente elástica.

O governo garantiu a ampliação do crédito e o financiamento dos bancos públicos para contrabalançar a retração das linhas dos bancos privados e suprir as necessidades do setor produtivo. Medidas de desoneração tributária de produtos de consumo duráveis e de construção civil, entre outros, estimularam a demanda doméstica, que também respondeu à manutenção da confiança dos consumidores, amenizando os efeitos negativos da crise (BRASIL, 2010).

Sicsú (2009) destaca as medidas para ampliar a liquidez/crédito e a demanda doméstica: a) aumento real superior a $6 \%$ do salário mínimo; b) reajuste dos benefícios pagos pela previdência, superiores a um salário mínimo, de acordo com a inflação passada - ou seja, não houve perda de poder de compra de 2008 para 2009; c) ampliação do crédito direcionado ofertado pelas instituições financeiras,

$1 \quad$ Dados em números índices com ajuste sazonal, média $2002=100$.

2 Para detalhes, consultar o Decreto $n^{\circ}$ 6.687, de 11 de dezembro de 2008 e o Decreto $n^{\circ} 6.743$, de 15 de janeiro 2009. 
especialmente as púbicas, como o BNDES, a Caixa Econômica e o Banco do Brasil; d) criação de duas novas alíquotas de imposto de renda sobre a pessoa física, o que fez aumentar de forma significativa a renda disponível; e) inclusão de mais de 1,3 milhão de famílias no programa Bolsa-família, durante o ano de 2009; f) concentração de esforços para realização dos projetos de investimento do Programa de Aceleração do Crescimento (PAC); g) redução da meta de superávit primário anual, de 4,3\% do PIB para 2,5\%; h) lançamento do programa habitacional de construção de 1 milhão de moradias; e i) manutenção/ampliação dos gastos públicos com pessoal, programas sociais e atividades finalísticas do Estado brasileiro.

O conjunto de medidas, visando à recuperação da economia, foi suficiente para manter o consumo das famílias em trajetória ascendente e para que os investimentos empresariais produtivos se recuperassem mais rapidamente, conforme se observa no Gráfico 2.

Gráfico 2 - Consumo das famílias e formação bruta de capital fixo de 2007 a $2010^{3}$

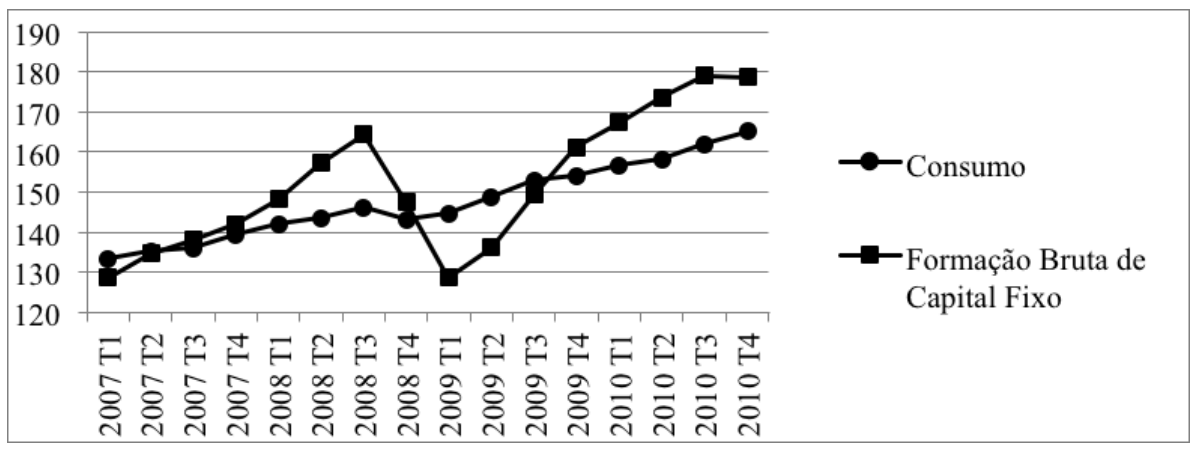

Fonte: Elaboração própria a partir de dados de IBGE (2008).

O objetivo deste artigo é investigar os efeitos de curto prazo da adoção de uma política fiscal anticíclica, de redução de alíquota de impostos, sobre a economia. Especificamente, os efeitos da redução do IPI para o setor automobilístico (nos subsetores automóveis/camionetas/utilitários e caminhões/ônibus), no ano de 2009, sobre a produção do setor e de outros setores, bem como no mercado de trabalho. Para tanto será utilizado o ferramental de matriz insumo-produto.

Este artigo está dividido em cinco seções, além desta introdução: a segunda seção apresenta os procedimentos metodológicos da teoria insumo-produto; a terceira seção discute a importância do setor automobilístico na economia brasileira; a quarta seção é dedicada à análise dos impactos de curto prazo da política fiscal contracíclica; e, para finalizar, a quinta seção reserva-se às considerações finais.

3 Dados trimestrais e índices encadeados dessazonalizados (média $1995=100$ ). 


\section{Metodologia}

$\mathrm{Na}$ literatura ${ }^{4}$ tem se utilizado frequentemente as matrizes insumo-produto como ferramenta importante em análises de estudos setoriais e de impacto. Os primeiros estudos sobre essa ferramenta se devem a Wassily Leontief, os quais foram realizados para as relações interindustriais, ou seja, de origem e destino de bens e serviços. Assim, o objetivo central do modelo insumo-produto é investigar as relações de interdependência entre os setores de uma economia.

O modelo insumo-produto é fundamentado em retornos constantes à escala, as funções de produção são lineares e homogêneas e o conjunto dos coeficientes técnicos diretos é considerado fixo. Tais coeficientes são representados por $a_{i j}=\frac{z_{i j}}{X_{j}} \mathrm{e}$ expressam a relação entre a produção dos setores e seus insumos, ou seja, $a_{i j}$ indica a quantidade de insumo do setor i necessária para a produção de uma unidade de produto do setor $j$, sendo $X_{j}$ a produção total do setor $j$.

Neste artigo, o modelo insumo-produto será analisado no enfoque setor versus setor, com abordagem da tecnologia baseada na indústria, que tem como hipótese a existência de participação constante de cada setor no mercado. Será utilizada a matriz insumo-produto de 2009, estimada de acordo com a metodologia de Guilhoto e Sesso Filho (2010, 2005).

\subsection{O Modelo Básico de Leontief e Multiplicadores}

O modelo básico de Leontief é dado pela equação 1, em que $X$ e $Y$ são vetores coluna de ordem $(n \times 1)$, respectivamente da produção total e da demanda final e $A$ representa a matriz dos coeficientes técnicos diretos, ou seja, fornece o impacto direto causado pelo aumento na demanda final.

$$
A X+Y=X
$$

A equação 2 expressa, a partir de alterações na demanda final, o nível de produção total necessária para satisfazê-la, e $(I-A)^{-1}$, representada por $B$, é a matriz de coeficientes técnicos diretos e indiretos, ou a matriz inversa de Leontief, que agrupa informações que possibilitam identificar o impacto total de uma variação unitária na demanda final sobre todo o sistema produtivo. Por meio da matriz $B$ também é possível se obter os multiplicadores do tipo I, cujos efeitos relacionam-se à demanda intermediária.

4 Incluem-se nessa literatura, por exemplo, Guilhoto, Polenske e Liu (2010) e Guilhoto e Costa (2011).

FERNANDES, C. B. S.; GUILHOTO, J. J. M. Análise de Impacto de Curto Prazo da Políitica... 


$$
X=(I-A)^{-1} Y
$$

De acordo com Miller e Blair (2009), através do multiplicador de produção é possível obter o valor total de produção de toda a economia, que é acionado para atender a variação de uma unidade na demanda final de determinado setor $j$ por:

$$
M P_{j}=\sum_{i=1}^{n} b_{i j}
$$

em que $b_{i j}$ é um elemento da matriz inversa de Leontief.

O impacto total direto e indireto $\left(G V_{j}\right)$, de uma determinada variável, para cada unidade monetária produzida para a demanda final é obtido por:

$$
\begin{gathered}
G V_{j}=\sum_{i=1}^{n} b_{i j} v_{i} \\
v_{i}=\frac{V_{j}}{X_{i}}
\end{gathered}
$$

sendo $v_{i}$ o coeficiente direto da variável analisada.

O multiplicador de emprego, que demonstra o número de empregos gerados na economia para cada vaga gerada no setor de interesse, é calculado através da divisão dos geradores de emprego pelo coeficiente de emprego correspondente, conforme a equação $6 .^{5}$

$$
M V_{i}=\frac{G V_{j}}{v_{i}}
$$

A partir da equação 1 pode-se computar o impacto de alterações na demanda final, sobre alguma variável em questão, por exemplo, sobre o PIB e emprego, como nas equações 7 e 8 .

$$
\begin{gathered}
\Delta X=(I-A)^{-1} \Delta Y \\
\Delta V=\hat{v} \Delta X
\end{gathered}
$$

Nas equações 7 e $8, \Delta Y, \Delta X$ e $\Delta V$ são vetores-coluna que representam, respectivamente, a estratégia setorial, os impactos sobre o volume da produção e

5 De acordo com Guilhoto (2011), a partir da equação 6 é possível se encontrar, além do multiplicador de emprego, outros, como os de importações, impostos, ou qualquer outra variável para cada unidade diretamente gerada a partir delas. 
o impacto sobre a variável desejada. Além disto, $\hat{v}$ é uma matriz diagonal ( $n x n)$, em que os elementos da diagonal são os coeficientes da variável em questão, obtidos conforme a equação 5 .

\subsection{Os Índices de Hirschman-Rasmussen}

Utilizando o modelo básico de Leontief, definido anteriormente, é possível calcular os índices que sintetizam as ligações para trás, o quanto um setor demanda dos outros setores, e para frente, quanto um determinado setor é demandado pelos outros, como desenvolvido por Rasmussen (1956) e Hirschman (1958).

A partir da matriz inversa de Leontief, B, pode-se definir: $b_{i j}$ é um elemento; B* é a média de todos seus elementos; e $B_{*_{j}}$ e $B_{i^{*}}$ são as somas, respectivamente, das colunas e das linhas da matriz. Considerando a matriz de Ghosh, ${ }^{6}$ representada por $G$, pode-se definir: $G^{*}$ é a média de todos os elementos de $G$; e $G_{i^{*}}$ é a soma de uma linha típica de $G$. Assim, os índices de ligações para trás $\left(U_{j}\right)$ e para frente $\left(U_{i}\right)$ são obtidos por:

$$
\begin{aligned}
& U_{j}=\left[B_{*_{j}} / n\right] / B^{*} \\
& U_{i}=\left[G_{i^{*}} / n\right] / G^{*}
\end{aligned}
$$

Setores que apresentarem índices de ligações para trás ou para frente superiores à unidade indicam que estão acima da média da economia e, portanto, são considerados setores chaves para o crescimento econômico.

\section{3 Índices Puros de Ligação}

Os índices de ligação puros determinam a importância do setor para a economia em termos da produção de cada setor e da sua interação com outros setores. Os setores que apresentarem índices mais expressivos, sendo então os mais importantes dentro da economia, normalmente possuem elevada interação e produção.

De acordo com Guilhoto, Sonis e Hewings (2005), os cálculos se dão a partir de uma matriz A de coeficientes técnicos:

$$
A=\left[\begin{array}{cc}
A_{j j} & A_{j r} \\
A_{r j} & A_{r r}
\end{array}\right]=\left[\begin{array}{cc}
A_{j j} & A_{j r} \\
A_{r j} & 0
\end{array}\right]+\left[\begin{array}{cc}
0 & 0 \\
0 & A_{r r}
\end{array}\right]=A_{j}+A_{r}
$$

$6 \quad$ Para detalhes, consultar Miller e Blair (2009).

FERNANDES, C. B. S.; GUILHOTO, J. J. M. Análise de Impacto de Curto Prazo da Política... 
em que: $A_{\mathrm{ij}}$ e $A_{r r}$ são matrizes dos insumos diretos destinados ao setor $\mathrm{j}$ e originados dentro do próprio setor e destinados ao resto da economia e originados dentro do próprio resto da economia, respectivamente; e $A_{r j}$ e $A_{j r}$ representam matrizes dos insumos que o setor $j$ adquire do resto da economia e vice-versa.

$$
\begin{aligned}
B=(I-A)^{-1}= & {\left[\begin{array}{ll}
B_{j j} & B_{j r} \\
B_{r j} & B_{r r}
\end{array}\right]=\left[\begin{array}{cc}
\Delta_{j j} & 0 \\
0 & \Delta_{r r}
\end{array}\right]\left[\begin{array}{cc}
\Delta_{j} & 0 \\
0 & \Delta_{r}
\end{array}\right]\left[\begin{array}{cc}
I & A_{j r} \Delta_{r} \\
A_{r j} \Delta_{j} & I
\end{array}\right] } \\
& \Delta_{j}=\left(I-A_{i j}\right)^{-1} \\
& \Delta_{r}=\left(I-A_{r r}\right)^{-1} \\
& \Delta_{j j}=\left(I-\Delta_{j} A_{j r} \Delta_{r} A_{r j}\right)^{-1} \\
& \Delta_{r r}=\left(I-\Delta_{j} A_{r j} \Delta_{j} A_{j r}\right)^{-1}
\end{aligned}
$$

Assim, obtém-se: o índice puro de ligação para trás $(P B L)$, que demonstra o impacto do valor da produção total do setor $j$ sobre o resto da economia; o índice puro de ligação para frente (PFL), que representa o impacto do valor da produção total do resto da economia sobre o setor j; e o índice puro total das ligações, que é a soma dos dois índices, expressos em valores correntes.

$$
\begin{gathered}
P B L=\Delta_{r} A_{r j} \Delta_{j} Y_{j} \\
P F L=\Delta_{j} A_{j r} \Delta_{r} Y_{r}
\end{gathered}
$$

É possível também calcular os índices puros de ligações normalizados, quando se pretende fazer uma análise comparativa com os índices de ligações de Hirschman-Rasmussen:

$$
\begin{aligned}
& P B L N_{i}=P B L_{i} /\left(\sum_{i=1}^{n} P B L_{i} / n\right) \\
& \text { PFLN }_{i}=P F L_{i} /\left(\sum_{i=1}^{n} P F L_{i} / n\right) \\
& \operatorname{PTLN}_{i}=P T L_{i} /\left(\sum_{i=1}^{n} P T L_{i} / n\right) \\
& P T L=P B L+P F L
\end{aligned}
$$


As equações 15, 16 e 17 representam, nessa ordem, os índices puro de ligação para trás normalizado, puro de ligações para frente normalizado e puro total normalizado, sendo que o índice puro do total de ligações (PTL) de cada setor na economia é obtido através da equação 18.

\section{A Importância do Setor Automobilístico na Economia Brasileira}

A década de 1990 foi o período pelo qual a indústria automobilística passou por intensas transformações, o que ocasionou um aumento da demanda e da produção. Foram determinantes principais desse resultado, de acordo com Laplane e Sarti (1996), a abertura comercial, os incentivos fiscais para carros populares e a integração econômica regional no Mercado Comum do Sul (Mercosul). ${ }^{7}$ No início de tal década, após um período de retração da produção e das vendas no mercado interno, a indústria automobilística enfrentou um processo de integração ao mercado mundial, com fortes pressões para eficácia e redução dos custos. Além disso, esse período marcou também o retorno de medidas governamentais voltadas para esse setor. O diagnóstico de estagnação gerou a necessidade de elaborar um plano para o setor, com o objetivo de modernizar, recuperar e desenvolver o mercado. Estabeleceu-se o acordo automotivo entre o governo, os trabalhadores e as montadoras, no qual foram traçadas diversas metas para o setor, como a redução de carga tributária (IPI e ICMS), a redução de margens de lucro das montadoras, dos fabricantes de autopeças e das concessionárias, a redução de preço dos automóveis, a manutenção do emprego, a ampliação do financiamento para caminhões e ônibus e a implementação de financiamento para carros de passeio (SANTOS; BURITY, 2002).

A estabilidade econômica, a demanda de veículos e a concorrência com a Argentina geravam incertezas no setor. Assim, o regime automotivo, criado e reformulado entre 1995 e 1997, com a inclusão dos estados menos desenvolvidos, tinha como objetivo a retomada do investimento e o ganho de competitividade para o aumento das exportações. Esse regime incluiu, além de incentivos fiscais para a implantação de empresas no país, estímulos diferenciados para as empresas que decidissem instalar unidades em regiões menos desenvolvidas (SANTOS; BURITY, 2002).

Os incentivos do regime automotivo, a recuperação do mercado interno brasileiro, a ameaça de entrada de novos concorrentes como decorrência da abertura da economia e a criação do Mercosul atraíram uma forte onda de investimentos das montadoras transnacionais que ampliaram a capacidade, mudaram a estrutura territorial e estabeleceram novas tendências para o desenvolvimento do

7 Argumentos semelhantes são apresentados por Cecchini et al. (2007). 
setor. No final dos anos 1990, a produção de automóveis no Brasil estava territorialmente menos homogênea, contava com a participação de montadoras japonesas, rompendo com o monopólio das montadoras norte-americanas e europeias, e estava fortemente especializada na produção de automóveis de pequeno porte. Nesse contexto, a partir do ano 2000, a estrutura e a dinâmica da indústria automobilística no Brasil têm pouca relação com aquela que predominou desde sua implantação até o início dos anos 1990 (LAPLANE; SARTI, 1996).

As condições recentes da indústria automobilística brasileira são de destaque. Dados do Anuário da Indústria Automobilística Brasileira (2011) indicam que o Brasil está entre os maiores produtores mundiais de veículos. No ano de 2010 ficou com a sexta posição no ranking, atingindo uma produção de 3.646 milhões de veículos, logo após a Coreia do Sul, que produziu 4.272 milhões de unidades. No ranking de licenciamentos de veículos novos, o Brasil ficou com a quarta posição, com 3.515 milhões, precedido pelo Japão, que licenciou 4.956 milhões de veículos. Portanto, trata-se de um setor produtivo de destaque na economia brasileira.

A Tabela 1 demonstra de forma simples, para o ano de 2009, o comportamento de algumas variáveis macroeconômicas, como forma de representar a importância da indústria automobilística na economia brasileira. Entre as variáveis, o destaque está no peso dos bens da indústria automobilística na demanda final, em comparação à participação desse setor no PIB. Essa constatação indica que variações no consumo final provocarão fortes impactos na produção do setor. Dessa forma, justifica-se avaliar o impacto da demanda final, originada a partir da redução das alíquotas de IPI, sobre a produção do setor automobilístico e sua capacidade de geração de empregos, já que se trata de produtos de demanda final, com algumas exceções, como, por exemplo, caminhões, que geralmente são utilizados como bens de capital.

Tabela 1 - Participação da indústria automobilística na economia brasileira em 2009

\begin{tabular}{lllll}
\hline $\begin{array}{l}\text { Variáveis } \\
\text { macroe- } \\
\text { conômicas }\end{array}$ & $\begin{array}{l}\text { Total da } \\
\text { economia } \\
\text { (A) }\end{array}$ & $\begin{array}{l}\text { Automóveis } \\
\text { (B) }\end{array}$ & $\begin{array}{l}\text { Caminhões/ } \\
\text { onnibus (C) }\end{array}$ & $\begin{array}{l}\text { Participação em } \\
\text { porcentagem } \\
\text { da indústria } \\
\text { automobilística } \\
\text { (B+C)/(A) }\end{array}$ \\
\hline $\begin{array}{l}\text { Valor bruto de } \\
\text { produção }\end{array}$ & 5.480 .741 & 88.419 & 22.163 & $2,02 \%$ \\
$\begin{array}{l}\text { Valor adicio- } \\
\text { nado }\end{array}$ & 2.794 .379 & 10.482 & 3.417 & $0,5 \%$ \\
$\begin{array}{l}\text { Salários } \\
\text { Demanda }\end{array}$ & 1.114 .095 & 6.812 & 1.961 & $0,79 \%$ \\
final total & 3.211 .203 & 85.057 & 20.052 & $3,27 \%$ \\
\hline
\end{tabular}

Fonte: Elaboração própria a partir da matriz insumo-produto 2009. 
Bahia e Domingues (2010) argumentam, com base em dados da matriz insumo-produto de 2005, que automóveis são demandados principalmente pelo consumo interno das famílias $(51,9 \%)$, pelas exportações $(21,1 \%)$ e pelo investimento (20,3\%), enquanto que caminhões têm sua demanda concentrada em investimentos $(51,4 \%)$ e exportações $(31,9 \%)$. Comparando essas informações às da matriz insumo-produto de 2009, ${ }^{8}$ estimada por Guilhoto e Sesso Filho (2005, 2010), a heterogeneidade na demanda dos subsetores se mantém, porém com menor participação das exportações. Assim, da demanda total de automóveis, 54,63\% é destinada ao consumo das famílias, 33,39\% à formação bruta de capital fixo e 6,29\% às exportações. Para caminhões, 79,97\% da demanda total é destinada a investimentos e 10,67\% às exportações. Esses dados indicam uma concentração da produção do setor automobilístico no mercado interno.

A desoneração sobre os veículos automotores impulsionou as vendas e a produção do setor, amenizando as perdas em empregos. As vendas de veículos, que de novembro de 2008 a fevereiro de 2009 caíram para valores inferiores a 200 mil unidades/mês, em março voltaram para um patamar superior a $250 \mathrm{mil}$ unidades/mês. Nos meses de abril e maio, as vendas alcançaram mais de $200 \mathrm{mil}$ unidades, número considerado muito bom (SICSÚ, 2009). Isso pode ser observado no Gráfico 3. As vendas de veículos têm trajetória ascendente desde o início do ano de 2009, sempre apresentando picos nos meses previstos para retorno do padrão normal das alíquotas, chegando a atingir mais de 308 mil, em setembro de 2009, e mais de 350 mil unidades, em março de 2010, com o fim da desoneração.

Gráfico 3 - Licenciamentos de veículos, em milhares de unidades (jan. 2009 a dez. 2010)

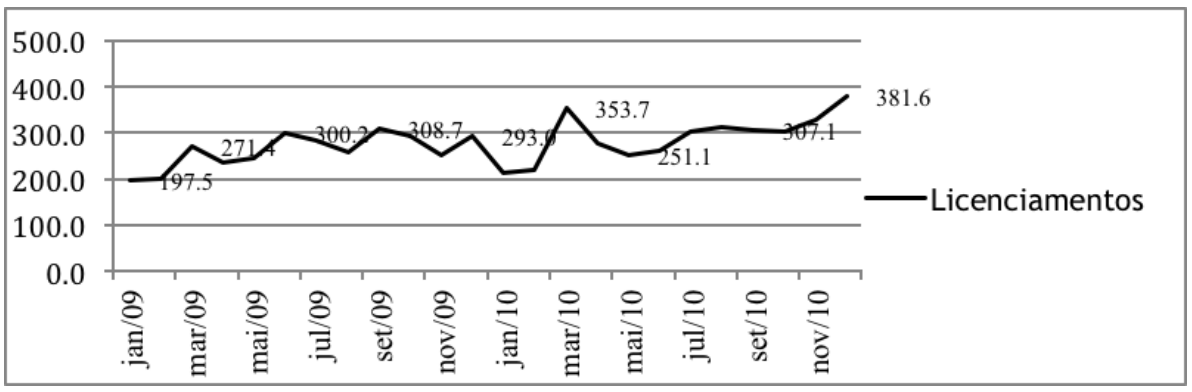

Fonte: Elaboração própria a partir de dados da Associação Nacional dos Fabricantes de Veículos Automotores (2009, 2010).

Apesar das vendas de veículos entrarem em trajetória descendente após o fim da desoneração em março de 2010, esse ano finalizou com uma quantidade de vendas superior à máxima que se obteve durante o período de redução do IPI. Isso

8 A matriz insumo-produto de 2009, e de outros anos, está disponível em Universidade de São Paulo (2012). 
se explica pela intensidade do nível de atividade 9 no ano e, consequentemente, de renda, como também por uma nova prorrogação da desoneração até 31 de dezembro de 2011 para caminhões, reboques e tratores, caminhonetes e picapes. O setor automotivo é um setor extremamente capaz de impulsionar a produção industrial, devido aos seus fortes efeitos de encadeamento com vários outros setores da estrutura industrial brasileira, sendo possivel afirmar que boa parte do crescimento da indústria brasileira no período recente se deve ao bom desempenho desse setor (NEGRI et al., 2008).

De outra forma, Bahia e Domingues (2010) afirmam que a cadeia automotiva é a mais importante da economia brasileira quanto à indução direta e indireta de crescimento para todos os demais setores, tanto que todos os ciclos econômicos brasileiros desde 1967 se iniciaram nos setores de bens de consumo duráveis, em particular da cadeia automotiva. Dessa forma, é importante analisar as articulações do setor automobilístico e demais setores da economia. A matriz insumo-produto é uma ferramenta que possibilita esse tipo de estudo, bem como estimar os impactos provocados no emprego e produção da economia a partir da desoneração do IPI.

Na metodologia de insumo-produto uma forma de se analisar a importância da indústria automobilística para a economia brasileira é através dos índices de ligação, conforme a Tabela 2. Destacam-se os índices de ligação para trás, tanto o de Hirschman-Rasmussen quanto o puro, que são mais elevados que a média da economia, ou seja, essa indústria é maior demandante de produtos de outros setores da economia, na forma de insumos, do que ofertante de insumos para os demais setores.

Os índices de Hirschman-Rasmussen para trás, dos subsetores de automóveis, camionetas e utilitários $(1,27)$ e de caminhões e ônibus $(1,25)$, os colocam, respectivamente, na segunda e terceira posição entre os 56 setores da economia, perdendo somente para o setor de alimentos e bebidas $(1,28)$. Isso indica que uma mudança na demanda final do setor geraria fortes impactos na economia, pois ele depende de muitos outros setores no seu processo de produção. Assim, por exemplo, uma redução de produção do setor automobilístico, decorrente de redução na demanda, levaria à redução de produção de outros setores na economia, por exemplo, o de peças e acessórios.

O setor de peças e acessórios tem um papel central como o principal fornecedor dos segmentos finais da cadeia de automóveis e caminhões. Destacam-se como principais elementos de ligação para trás: os setores de aços e derivados, máquinas e equipamentos, material eletrônico, produtos de metal e artigos de borracha e plástico. O setor de aço e derivados representa um dos insumos mais

9 De acordo com dados do IBGE (2011), no ano de 2010 o crescimento do PIB foi de 7,5\%. O maior registrado desde 1986. 
importantes para todos os subsetores da cadeia automotiva, especialmente para autopeças (NEGRI et al., 2008; BAHIA; DOMINGUES, 2010).

Os índices de ligação para frente fortalecem a constatação desses autores. Todos os setores por eles citados apresentam índices de ligação para frente superiores à média da economia, estando inclusive entre os dez mais elevados de toda a economia, sendo que peças e acessórios, que forneceu $40,17 \%$ do total de sua produção a automóveis e caminhões,$^{10}$ apresenta índice de 1,36. Analisando os índices puros - que consideram o valor monetário e absoluto da produção de determinado setor, como já explicitado -, observa-se que os índices para trás são mais representativos, sendo de 3,17, para automóveis, e de 0,72 para caminhões. A diferença elevada entre os valores certamente se explica pela quantidade produzida de automóveis ser extremamente superior à de caminhões e ônibus. Dados da Associação Nacional dos Fabricantes de Veículos Automotores (2011) indicam que, enquanto a produção do primeiro em 2009 foi superior a três milhões de unidades, a do segundo foi de aproximadamente 158 mil unidades.

Tabela 2 - Índices de ligações de Hirschman-Rasmussen (H-R) e puros dos setores do Brasil em 2009

\begin{tabular}{llllll}
\hline \multirow{2}{*}{\multicolumn{1}{c}{ Setor }} & \multicolumn{1}{c}{ Índice H-R } & \multicolumn{4}{c}{ Índice puro } \\
\cline { 2 - 7 } & Trás & Frente & Trás & Frente & Total \\
\hline $\begin{array}{llllll}\text { Agricultura, silvicultura, exploração } \\
\text { florestal }\end{array}$ & 0,88 & 1,12 & 1,06 & 2,82 & 1,94 \\
Pecuária e pesca & 1 & 1,11 & 0,72 & 1,65 & 1,18 \\
Petróleo e gás natural & 1,01 & 1,59 & 0,46 & 1,64 & 1,05 \\
Minério de ferro & 0,95 & 0,87 & 0,41 & 0,17 & 0,29 \\
Outros da indústria extrativa & 1,04 & 1,61 & 0,07 & 0,45 & 0,26 \\
Alimentos e bebidas & 1,28 & 0,84 & 6,95 & 1,84 & 4,4 \\
Produtos do fumo & 1,17 & 0,56 & 0,36 & 0 & 0,18 \\
Têxteis & 1,03 & 1,1 & 0,27 & 0,66 & 0,47 \\
Artigos do vestuário e acessórios & 1 & 0,61 & 0,91 & 0,08 & 0,49 \\
Artefatos de couro e calçados & 1,09 & 0,66 & 0,48 & 0,01 & 0,24 \\
Produtos de madeira (exclusive & 1,04 & 1,3 & 0,06 & 0,42 & 0,24 \\
móveis) & & & & & \\
Celulose e produtos de papel & 1,12 & 1,2 & 0,41 & 0,7 & 0,56 \\
Jornais, revistas e discos & 0,93 & 1,34 & 0,22 & 0,74 & 0,48 \\
Refino de petróleo e coque & 1,17 & 1,39 & 1,12 & 2,72 & 1,92 \\
\hline
\end{tabular}

10 Dado obtido com base na matriz insumo-produto de 2009, estimada por Guilhoto e Sesso Filho (2005, 2010). 


\section{Setor}

\begin{tabular}{|c|c|c|c|c|c|}
\hline Álcool & 1,11 & 1,13 & 0,32 & 0,31 & 0,32 \\
\hline Produtos químicos & 1,15 & 1,64 & 0,21 & 1,51 & 0,86 \\
\hline Fabricação de resina e elastômeros & 1,17 & 1,59 & 0,11 & 0,49 & 0,3 \\
\hline Produtos farmacêuticos & 0,94 & 0,71 & 0,61 & 0,25 & 0,43 \\
\hline Defensivos agrícolas & 1,2 & 1,57 & 0,05 & 0,41 & 0,23 \\
\hline Perfumaria, higiene e limpeza & 1,09 & 0,69 & 0,62 & 0,11 & 0,37 \\
\hline Tintas, vernizes, esmaltes e lacas & 1,05 & 1,18 & 0,05 & 0,28 & 0,17 \\
\hline $\begin{array}{l}\text { Produtos e preparados químicos } \\
\text { diversos }\end{array}$ & 1,09 & 1,48 & 0,06 & 0,34 & 0,2 \\
\hline Artigos de borracha e plástico & 1,07 & 1,38 & 0,19 & 1,44 & 0,81 \\
\hline Cimento & 1,1 & 1,31 & 0,02 & 0,3 & 0,16 \\
\hline $\begin{array}{l}\text { Outros produtos de minerais não } \\
\text { metálicos }\end{array}$ & 1,03 & 1,25 & 0,07 & 1,02 & 0,54 \\
\hline Fabricação de aço e derivados & 1,06 & 1,36 & 0,28 & 1,55 & 0,91 \\
\hline Metalurgia de metais não ferrosos & 1,14 & 1,26 & 0,31 & 0,55 & 0,43 \\
\hline $\begin{array}{l}\text { Produtos de metal (exclusive máqui- } \\
\text { nas e equipamentos) }\end{array}$ & 1 & 1,22 & 0,43 & 1,23 & 0,83 \\
\hline $\begin{array}{l}\text { Máquinas e equipamentos, inclusive } \\
\text { manutenção e reparos }\end{array}$ & 1,09 & 0,8 & 1,74 & 0,52 & 1,13 \\
\hline Eletrodomésticos & 1,14 & 0,59 & 0,43 & 0,02 & 0,22 \\
\hline $\begin{array}{l}\text { Máquinas para escritório e equipa- } \\
\text { mentos de informática }\end{array}$ & 1,07 & 0,64 & 0,5 & 0,04 & 0,27 \\
\hline $\begin{array}{l}\text { Máquinas, aparelhos e materiais } \\
\text { elétricos }\end{array}$ & 1,08 & 1,16 & 0,4 & 0,76 & 0,58 \\
\hline $\begin{array}{l}\text { Material eletrônico e equipamentos de } \\
\text { comunicações }\end{array}$ & 1,12 & 0,88 & 0,47 & 0,24 & 0,36 \\
\hline $\begin{array}{l}\text { Aparelhos médico-hospitalar, de me- } \\
\text { dida e ópticos }\end{array}$ & 0,86 & 0,69 & 0,2 & 0,06 & 0,13 \\
\hline Automóveis, camionetas e utilitários & 1,27 & 0,57 & 3,17 & 0,02 & 1,6 \\
\hline Caminhões e ônibus & 1,25 & 0,63 & 0,72 & 0,03 & 0,38 \\
\hline $\begin{array}{l}\text { Peças e acessórios para veículos auto- } \\
\text { motores }\end{array}$ & 1,14 & 1,36 & 0,17 & 1,54 & 0,86 \\
\hline Outros equipamentos de transporte & 1,12 & 0,78 & 0,54 & 0,08 & 0,31 \\
\hline
\end{tabular}


Setor

Móveis e produtos das indústrias diversas

Eletricidade e gás, água, esgoto e limpeza urbana

\begin{tabular}{|c|c|c|c|c|c|}
\hline \multirow{2}{*}{ Setor } & \multicolumn{2}{|c|}{ Índice $\mathbf{H}-\mathbf{R}$} & \multicolumn{3}{|c|}{ Índice puro } \\
\hline & Trás & Frente & Trás & Frente & Total \\
\hline $\begin{array}{l}\text { Móveis e produtos das indústrias } \\
\text { diversas }\end{array}$ & 1,01 & 0,73 & 0,83 & 0,25 & 0,54 \\
\hline $\begin{array}{l}\text { Eletricidade e gás, água, esgoto e } \\
\text { limpeza urbana }\end{array}$ & 0,91 & 1,25 & 0,69 & 2,7 & 1,69 \\
\hline Construção & 0,94 & 0,65 & 4,95 & 1,01 & 2,99 \\
\hline Comércio & 0,76 & 0,92 & 3,05 & 5,18 & 4,11 \\
\hline Transporte, armazenagem e correio & 0,95 & 1,15 & 2,06 & 3,85 & 2,95 \\
\hline Serviços de informação & 0,92 & 1,26 & 0,85 & 3,58 & 2,21 \\
\hline Intermediação financeira e seguros & 0,79 & 1,09 & 1,24 & 4,22 & 2,73 \\
\hline Serviços imobiliários e aluguel & 0,6 & 0,72 & 0,66 & 1,2 & 0,93 \\
\hline Serviços de manutenção e reparação & 0,73 & 0,99 & 0,23 & 0,47 & 0,35 \\
\hline Serviços de alojamento e alimentação & 1,03 & 0,67 & 2,59 & 0,53 & 1,56 \\
\hline Serviços prestados às empresas & 0,84 & 1,31 & 0,59 & 4,97 & 2,78 \\
\hline Educação mercantil & 0,8 & 0,6 & 0,64 & 0,09 & 0,37 \\
\hline Saúde mercantil & 0,88 & 0,58 & 1,7 & 0,09 & 0,9 \\
\hline $\begin{array}{l}\text { Serviços prestados às famílias e as- } \\
\text { sociativas }\end{array}$ & 0,91 & 0,71 & 1,96 & 0,56 & 1,26 \\
\hline Serviços domésticos & 0,53 & 0,54 & 0 & 0 & 0 \\
\hline Educação pública & 0,72 & 0,55 & 1,45 & 0,01 & 0,73 \\
\hline Saúde pública & 0,83 & 0,54 & 1,49 & 0 & 0,75 \\
\hline $\begin{array}{l}\text { Administração pública e seguridade } \\
\text { social }\end{array}$ & 0,8 & 0,57 & 5,87 & 0,27 & 3,08 \\
\hline Média da economia & 1,00 & 1,00 & 1,00 & 1,00 & 1,00 \\
\hline
\end{tabular}

Fonte: Elaboração própria.

Trás Frente Trás Frente Total

\begin{tabular}{|c|c|c|c|c|c|}
\hline \multirow{2}{*}{ Setor } & \multicolumn{2}{|c|}{ Índice H-R } & \multicolumn{3}{|c|}{ Índice puro } \\
\hline & Trás & Frente & Trás & Frente & Total \\
\hline $\begin{array}{l}\text { Móveis e produtos das indústrias } \\
\text { diversas }\end{array}$ & 1,01 & 0,73 & 0,83 & 0,25 & 0,54 \\
\hline $\begin{array}{l}\text { Eletricidade e gás, água, esgoto e } \\
\text { limpeza urbana }\end{array}$ & 0,91 & 1,25 & 0,69 & 2,7 & 1,69 \\
\hline Construção & 0,94 & 0,65 & 4,95 & 1,01 & 2,99 \\
\hline Comércio & 0,76 & 0,92 & 3,05 & 5,18 & 4,11 \\
\hline Transporte, armazenagem e correio & 0,95 & 1,15 & 2,06 & 3,85 & 2,95 \\
\hline Serviços de informação & 0,92 & 1,26 & 0,85 & 3,58 & 2,21 \\
\hline Intermediação financeira e seguros & 0,79 & 1,09 & 1,24 & 4,22 & 2,73 \\
\hline Serviços imobiliários e aluguel & 0,6 & 0,72 & 0,66 & 1,2 & 0,93 \\
\hline Serviços de manutenção e reparação & 0,73 & 0,99 & 0,23 & 0,47 & 0,35 \\
\hline Serviços de alojamento e alimentação & 1,03 & 0,67 & 2,59 & 0,53 & 1,56 \\
\hline Serviços prestados às empresas & 0,84 & 1,31 & 0,59 & 4,97 & 2,78 \\
\hline Educação mercantil & 0,8 & 0,6 & 0,64 & 0,09 & 0,37 \\
\hline Saúde mercantil & 0,88 & 0,58 & 1,7 & 0,09 & 0,9 \\
\hline $\begin{array}{l}\text { Serviços prestados às famílias e as- } \\
\text { sociativas }\end{array}$ & 0,91 & 0,71 & 1,96 & 0,56 & 1,26 \\
\hline Serviços domésticos & 0,53 & 0,54 & 0 & 0 & 0 \\
\hline Educação pública & 0,72 & 0,55 & 1,45 & 0,01 & 0,73 \\
\hline Saúde pública & 0,83 & 0,54 & 1,49 & 0 & 0,75 \\
\hline $\begin{array}{l}\text { Administração pública e seguridade } \\
\text { social }\end{array}$ & 0,8 & 0,57 & 5,87 & 0,27 & 3,08 \\
\hline Média da economia & 1,00 & 1,00 & 1,00 & 1,00 & 1,00 \\
\hline
\end{tabular}

$\begin{array}{lllll}0,91 & 1,25 & 0,69 & 2,7 & 1,69\end{array}$

\section{Índice H-R Índice puro}

Conforme apresentado na Tabela 3, o multiplicador de produção - que permite analisar o impacto de uma variação na demanda final do setor de interesse sobre a produção total da economia - também revela a importância da indústria automobilística, pois, entre todos os setores da economia, ficou com a segunda posição no ano de 2009, perdendo somente para o setor de alimentos e bebidas, cujo multiplicador é de 2,40. Assim, a cada 1 milhão de unidades monetárias destinadas à demanda final, o setor de automóveis gera uma ampliação de 2,39 milhões na produção dos demais setores da economia, e caminhões gera 2,36 milhões, valores bem acima da média da economia. Dessa forma, outros setores da economia 
precisam crescer para atender a um aumento de demanda no setor automobilístico, expressando o padrão dinamizador do setor. Bahia e Domingues (2010) estimaram valores próximos a esses para 2005, sendo respectivamente de 2,23 e 2,47.

Avaliando a importância do setor automobilístico (automóveis e caminhões) no mercado de trabalho brasileiro, trata-se de um setor pouco intensivo em mão de obra e mais em tecnologia, o que pode ser constatado pelos coeficiente de emprego (razão entre o números de empregos do setor e a sua produção total) apresentados na Tabela 3, os quais ficam muito distantes da média da economia. Apesar disso, não se deve minimizar a importância do setor automobilístico nesse âmbito da economia, pois os geradores de emprego (que medem a geração de empregos por variação de um milhão de reais da demanda final, de forma direta e indireta, isto é, computando-se os empregos que se originaram tanto dos efeitos do aumento da demanda final quanto dos efeitos subsequentes de aumento da demanda intermediária) de suas atividades apresentam resultados superiores a 14 postos de trabalho. Especificamente, na geração de empregos e entre os 56 setores da economia, automóveis e caminhões ficam nas posições 37 e 42 , respectivamente.

Os multiplicadores de emprego, ${ }^{11}$ que fornecem o número de postos de trabalho gerados na economia para cada emprego gerado no setor automobilístico, incorporando os efeitos direto e indireto, destacam-se na Tabela 3. Assim, por exemplo, um aumento na demanda de automóveis e caminhões gera um aumento de sua produção e do número de trabalhadores empregados e, consequentemente, gera aumento na produção e no número de trabalhadores do setor de peças e acessórios. Paralelamente, podem ocorrer aumentos da produção e de empregos de outros setores (elementos de ligação para trás citados anteriormente) devido à intensa relação setorial entre eles, gerando efeitos de retroalimentação.

Os multiplicadores de emprego ficam acima da média da economia, sendo mais elevados para automóveis, em relação a caminhões. Enquanto o primeiro gera para cada emprego direto criado mais de 15 empregos por toda a economia, o segundo gera mais de 13 empregos diretos e indiretos. Comparando-se aos outros setores da economia, os multiplicadores de emprego de automóveis e caminhões ficam, respectivamente, na quarta e quinta posição, o que é uma posição boa, pois no total são 56 setores, indicando a importância do setor automobilístico para a economia brasileira. Porém, a diferença é elevada se compararmos ao setor de refino de petróleo e coque, o líder, que apresenta multiplicador de emprego superior a 57.

11 Os multiplicadores de emprego apresentados na Tabela 3 são do tipo I. Os multiplicadores de emprego do tipo II incluem, além dos efeitos direto e indiretos, os efeitos renda ou induzidos. Estes últimos não são apresentados neste artigo porque nosso interesse é analisar os efeitos de uma variação inicial na demanda final, e não os efeitos de novos aumentos da demanda final que tendem a ocorrer em função do primeiro. 
Tabela 3 - Comportamento do emprego e da produção no setor automobilístico (2009)

\begin{tabular}{|c|c|c|c|c|}
\hline Setor & $\begin{array}{l}\text { Coeficiente } \\
\text { de emprego }\end{array}$ & $\begin{array}{l}\text { Gerador de } \\
\text { emprego }\end{array}$ & $\begin{array}{l}\text { Multipli- } \\
\text { cador de } \\
\text { emprego }\end{array}$ & $\begin{array}{l}\text { Multipli- } \\
\text { cador de } \\
\text { produção }\end{array}$ \\
\hline $\begin{array}{l}\text { Agricultura, silvicultu- } \\
\text { ra, exploração florestal }\end{array}$ & 66,61 & 76,58 & 1,15 & 1,65 \\
\hline Pecuária e pesca & 50,31 & 69,51 & 1,38 & 1,88 \\
\hline Petróleo e gás natural & 0,78 & 12,08 & 15,45 & 1,91 \\
\hline Minério de ferro & 1,23 & 9,35 & 7,60 & 1,78 \\
\hline $\begin{array}{l}\text { Outros da indústria } \\
\text { extrativa }\end{array}$ & 10,06 & 20,81 & 2,07 & 1,96 \\
\hline Alimentos e bebidas & 6,68 & 44,50 & 6,67 & 2,40 \\
\hline Produtos do fumo & 1,84 & 40,56 & 22,03 & 2,19 \\
\hline Têxteis & 22,88 & 41,62 & 1,82 & 1,94 \\
\hline $\begin{array}{l}\text { Artigos do vestuário e } \\
\text { acessórios }\end{array}$ & 46,11 & 64,15 & 1,39 & 1,87 \\
\hline $\begin{array}{l}\text { Artefatos de couro e } \\
\text { calçados }\end{array}$ & 25,64 & 43,51 & 1,70 & 2,06 \\
\hline $\begin{array}{l}\text { Produtos de madeira } \\
\text { (exclusive móveis) }\end{array}$ & 23,83 & 46,16 & 1,94 & 1,95 \\
\hline $\begin{array}{l}\text { Celulose e produtos de } \\
\text { papel }\end{array}$ & 4,54 & 23,44 & 5,16 & 2,10 \\
\hline $\begin{array}{l}\text { Jornais, revistas e } \\
\text { discos }\end{array}$ & 10,20 & 19,76 & 1,94 & 1,75 \\
\hline $\begin{array}{l}\text { Refino de petróleo e } \\
\text { coque }\end{array}$ & 0,16 & 9,24 & 57,29 & 2,19 \\
\hline Álcool & 4,92 & 45,10 & 9,17 & 2,08 \\
\hline Produtos químicos & 1,52 & 12,15 & 8,02 & 2,17 \\
\hline $\begin{array}{l}\text { Fabricação de resina e } \\
\text { elastômeros }\end{array}$ & 1,23 & 11,16 & 9,07 & 2,20 \\
\hline Produtos farmacêuticos & 2,97 & 13,27 & 4,46 & 1,76 \\
\hline Defensivos agrícolas & 1,42 & 15,47 & 10,87 & 2,26 \\
\hline $\begin{array}{l}\text { Perfumaria, higiene e } \\
\text { limpeza }\end{array}$ & 4,26 & 20,34 & 4,78 & 2,05 \\
\hline $\begin{array}{l}\text { Tintas, vernizes, esmal- } \\
\text { tes e lacas }\end{array}$ & 2,90 & 12,85 & 4,44 & 1,97 \\
\hline
\end{tabular}

continua... 


\begin{tabular}{|c|c|c|c|c|}
\hline Setor & $\begin{array}{l}\text { Coeficiente } \\
\text { de emprego }\end{array}$ & $\begin{array}{l}\text { Gerador de } \\
\text { emprego }\end{array}$ & $\begin{array}{l}\text { Multipli- } \\
\text { cador de } \\
\text { emprego }\end{array}$ & $\begin{array}{l}\text { Multipli- } \\
\text { cador de } \\
\text { produção }\end{array}$ \\
\hline $\begin{array}{l}\text { Produtos e preparados } \\
\text { químicos diversos }\end{array}$ & 5,47 & 16,65 & 3,05 & 2,05 \\
\hline $\begin{array}{l}\text { Artigos de borracha e } \\
\text { plástico }\end{array}$ & 7,02 & 16,52 & 2,35 & 2,01 \\
\hline Cimento & 1,48 & 13,36 & 9,05 & 2,07 \\
\hline $\begin{array}{l}\text { Outros produtos de } \\
\text { minerais não metálicos }\end{array}$ & 14,71 & 25,74 & 1,75 & 1,93 \\
\hline $\begin{array}{l}\text { Fabricação de aço e } \\
\text { derivados }\end{array}$ & 1,74 & 10,42 & 6,01 & 1,99 \\
\hline $\begin{array}{l}\text { Metalurgia de metais } \\
\text { não ferrosos }\end{array}$ & 3,82 & 14,13 & 3,70 & 2,14 \\
\hline $\begin{array}{l}\text { Produtos de metal } \\
\text { (exclusive máquinas e } \\
\text { equipamentos) }\end{array}$ & 11,86 & 19,52 & 1,65 & 1,88 \\
\hline $\begin{array}{l}\text { Máquinas e equipa- } \\
\text { mentos, inclusive ma- } \\
\text { nutenção e reparos }\end{array}$ & 6,63 & 16,15 & 2,43 & 2,05 \\
\hline Eletrodomésticos & 3,77 & 14,93 & 3,96 & 2,13 \\
\hline $\begin{array}{l}\text { Máquinas para es- } \\
\text { critório e equipamen- } \\
\text { tos de informática }\end{array}$ & 2,61 & 14,31 & 5,49 & 2,01 \\
\hline $\begin{array}{l}\text { Máquinas, aparelhos e } \\
\text { materiais elétricos }\end{array}$ & 5,57 & 15,20 & 2,73 & 2,04 \\
\hline $\begin{array}{l}\text { Material eletrônico } \\
\text { e equipamentos de } \\
\text { comunicações }\end{array}$ & 3,08 & 14,76 & 4,80 & 2,10 \\
\hline $\begin{array}{l}\text { Aparelhos médico- } \\
\text { hospitalar, de medida e } \\
\text { ópticos }\end{array}$ & 8,75 & 15,28 & 1,75 & 1,62 \\
\hline $\begin{array}{l}\text { Automóveis, camion- } \\
\text { etas e utilitários }\end{array}$ & 1,01 & 15,21 & 15,08 & 2,39 \\
\hline Caminhões e ônibus & 1,08 & 14,21 & 13,15 & 2,36 \\
\hline $\begin{array}{l}\text { Peças e acessórios para } \\
\text { veículos automotores }\end{array}$ & 5,13 & 15,66 & 3,05 & 2,14 \\
\hline
\end{tabular}




\begin{tabular}{|c|c|c|c|c|}
\hline Setor & $\begin{array}{l}\text { Coeficiente } \\
\text { de emprego }\end{array}$ & $\begin{array}{l}\text { Gerador de } \\
\text { emprego }\end{array}$ & $\begin{array}{l}\text { Multipli- } \\
\text { cador de } \\
\text { emprego }\end{array}$ & $\begin{array}{l}\text { Multipli- } \\
\text { cador de } \\
\text { produção }\end{array}$ \\
\hline $\begin{array}{l}\text { Outros equipamentos } \\
\text { de transporte }\end{array}$ & 3,41 & 13,07 & 3,83 & 2,10 \\
\hline $\begin{array}{l}\text { Móveis e produtos das } \\
\text { indústrias diversas }\end{array}$ & 20,49 & 33,64 & 1,64 & 1,90 \\
\hline $\begin{array}{l}\text { Eletricidade e gás, } \\
\text { água, esgoto e limpeza } \\
\text { urbana }\end{array}$ & 2,42 & 8,23 & 3,41 & 1,70 \\
\hline Construção & 24,13 & 34,26 & 1,42 & 1,77 \\
\hline Comércio & 32,29 & 38,16 & 1,18 & 1,43 \\
\hline $\begin{array}{l}\text { Transporte, armazen- } \\
\text { agem e correio }\end{array}$ & 14,62 & 23,56 & 1,61 & 1,79 \\
\hline Serviços de informação & 8,83 & 18,69 & 2,12 & 1,73 \\
\hline $\begin{array}{l}\text { Intermediação finan- } \\
\text { ceira e seguros }\end{array}$ & 3,09 & 9,09 & 2,94 & 1,49 \\
\hline $\begin{array}{l}\text { Serviços imobiliários e } \\
\text { aluguel }\end{array}$ & 2,61 & 4,57 & 1,75 & 1,12 \\
\hline $\begin{array}{l}\text { Serviços de manuten- } \\
\text { ção e reparação }\end{array}$ & 51,26 & 55,28 & 1,08 & 1,38 \\
\hline $\begin{array}{l}\text { Serviços de alojamento } \\
\text { e alimentação }\end{array}$ & 31,56 & 50,31 & 1,59 & 1,93 \\
\hline $\begin{array}{l}\text { Serviços prestados às } \\
\text { empresas }\end{array}$ & 22,79 & 30,32 & 1,33 & 1,58 \\
\hline Educação mercantil & 29,77 & 37,61 & 1,26 & 1,50 \\
\hline Saúde mercantil & 18,68 & 28,83 & 1,54 & 1,65 \\
\hline $\begin{array}{l}\text { Serviços prestados às } \\
\text { famílias e associativas }\end{array}$ & 36,40 & 47,79 & 1,31 & 1,72 \\
\hline Serviços domésticos & 187,79 & 187,79 & 1,00 & 1,00 \\
\hline Educação pública & 26,91 & 32,81 & 1,22 & 1,36 \\
\hline Saúde pública & 14,42 & 23,51 & 1,63 & 1,56 \\
\hline $\begin{array}{l}\text { Administração pública } \\
\text { e seguridade social }\end{array}$ & 11,97 & 18,45 & 1,54 & 1,50 \\
\hline Média da economia & 56 & 28,56 & 5,21 & 1,88 \\
\hline
\end{tabular}

Fonte: Elaboração própria. 


\section{Análise de Impacto de Curto Prazo da Política Fiscal Contracíclica}

A política fiscal é um instrumento de gestão da demanda agregada. Assim, em momentos de redução do nível de atividade econômica, se adotada a do tipo contracíclica, aquela que tende a impulsionar o nível de atividade, os resultados econômicos em termos de geração de renda e empregos serão positivos. Nessa linha, a estratégia do governo no período da crise financeira do final de 2008, de redução de impostos, com destaque à redução do IPI sobre veículos, causou bons resultados à economia, como citados anteriormente.

Um estudo do IPEA (2009) estimou, a partir da diferença entre as vendas previstas pelo modelo com os preços vigentes e as vendas com preços hipotéticos que vigorariam caso não tivesse havido a desoneração, que a política fiscal gerou um aumento na demanda do setor de 13,4\% durante o primeiro semestre do ano de 2009. Neste trabalho, para fins de análise de impacto, adota-se a hipótese de que esse valor foi válido para todo o ano de 2009.

Os resultados da análise de impacto, de aumento de $13,4 \%$ na demanda final de automóveis e caminhões em função da desoneração do IPI, que ocorreu entre final de 2008 e início de 2009, indicam, conforme a Tabela 4, que um aumento na demanda de tais bens afetaria, praticamente, todos os setores da economia. $\mathrm{O}$ impacto na produção bruta da economia seria de um aumento de mais de 32 bilhões de reais, sendo originado, em maior proporção, da participação de três setores: o de automóveis, com participação na produção em mais de 11 bilhões de reais; o de peças e acessórios para veículos automotores, com mais de 4 bilhões de reais; e o de caminhões, com mais de 2,7 bilhões. Naturalmente, esses setores incluem os diretamente beneficiados da desoneração e o seu maior fornecedor. Com relação ao impacto no PIB, haveria um aumento de quase 10 bilhões de reais em toda a economia, sendo que os setores de automóveis, comércio e peças e acessórios para veículos automotores os que mais contribuiriam.

No mercado de trabalho, ${ }^{12}$ o choque positivo de demanda, resultado da redução do IPI, geraria quase 12 mil postos de trabalho no setor de automóveis e mais de 3 mil em no de caminhões. Na economia brasileira provocaria um aumento no número de postos de trabalho em mais de 211 mil, sendo que, além dessas atividades produtivas citadas, destacam-se os setores de comércio, que agregaria aproximadamente 63 mil postos de trabalho, e o de peças e acessórios para veículos automotores, com mais de 21,5 mil. Esses resultados são superiores aos

12 Para fins de conferência calculou-se o impacto sobre o número de empregos para o setor automobilístico e para a economia no ano de 2008, utilizando o mesmo percentual de aumento da demando. Os resultados apontaram que os setores de automóveis, camionetas e utilitários aumentariam seus postos de trabalho em mais de 12 mil e o de caminhões em mais de 3 mil. $\mathrm{Na}$ economia como um todo, o impacto da elevação da demanda levaria a um aumento de 224.558 empregos. 
encontrados pelo IPEA (2009), os quais indicam que a redução do IPI contribuiu para manter entre 50 mil e 60 mil empregos diretos e indiretos na economia brasileira no primeiro semestre de 2009. Comparando dados do emprego das matrizes insumo-produto de 2008 e 2009, a perda em postos de trabalho foi de 2.141 entre esses anos.

Tabela 4 - Análise de impacto: aumento de 13,4\% na demanda final de automóveis como resultado da desoneração do IPI em 2009

\begin{tabular}{|c|c|c|c|}
\hline Setor & $\begin{array}{l}\text { Impacto na } \\
\text { produção } \\
\text { (R\$ milhões ) }\end{array}$ & $\begin{array}{l}\text { Impacto no PIB } \\
\text { (R\$ milhões ) }\end{array}$ & $\begin{array}{l}\text { Impacto no } \\
\text { emprego } \\
\text { (número de } \\
\text { ocupações) }\end{array}$ \\
\hline $\begin{array}{l}\text { Agricultura, silvicultura, } \\
\text { exploração florestal }\end{array}$ & 63,66 & 39,68 & 4370,42 \\
\hline Pecuária e pesca & 11,22 & 5,85 & 581,85 \\
\hline Petróleo e gás natural & 198,93 & 74,21 & 160,29 \\
\hline Minério de ferro & 119,28 & 60,61 & 151,27 \\
\hline $\begin{array}{l}\text { Outros da indústria extra- } \\
\text { tiva }\end{array}$ & 100,88 & 37,22 & 1045,91 \\
\hline Alimentos e bebidas & 48,41 & 9,28 & 333,06 \\
\hline Produtos do fumo & 0,00 & 0,00 & 0,01 \\
\hline Têxteis & 38,10 & 14,93 & 898,64 \\
\hline $\begin{array}{l}\text { Artigos do vestuário e } \\
\text { acessórios }\end{array}$ & 9,71 & 4,27 & 461,38 \\
\hline $\begin{array}{l}\text { Artefatos de couro e calça- } \\
\text { dos }\end{array}$ & 15,37 & 5,53 & 406,09 \\
\hline $\begin{array}{l}\text { Produtos de madeira (ex- } \\
\text { clusive móveis) }\end{array}$ & 28,62 & 12,10 & 702,85 \\
\hline $\begin{array}{l}\text { Celulose e produtos de } \\
\text { papel }\end{array}$ & 110,46 & 33,46 & 516,94 \\
\hline Jornais, revistas e discos & 105,38 & 55,87 & 1108,30 \\
\hline Refino de petróleo e coque & 483,13 & 103,55 & 80,33 \\
\hline Álcool & 31,43 & 10,73 & 159,38 \\
\hline Produtos químicos & 284,89 & 58,46 & 445,08 \\
\hline $\begin{array}{l}\text { Fabricação de resina e } \\
\text { elastômeros }\end{array}$ & 240,13 & 33,89 & 304,60 \\
\hline Produtos farmacêuticos & 7,03 & 3,50 & 21,54 \\
\hline Defensivos agrícolas & 22,92 & 4,27 & 33,61 \\
\hline
\end{tabular}




\begin{tabular}{|c|c|c|c|}
\hline Setor & $\begin{array}{l}\text { Impacto na } \\
\text { produção } \\
\text { (R\$ milhões ) }\end{array}$ & $\begin{array}{l}\text { Impacto no PIB } \\
\text { (R\$ milhões ) }\end{array}$ & $\begin{array}{l}\text { Impacto no } \\
\text { emprego } \\
\text { (número de } \\
\text { ocupações) }\end{array}$ \\
\hline $\begin{array}{l}\text { Perfumaria, higiene e } \\
\text { limpeza }\end{array}$ & 9,17 & 3,02 & 40,24 \\
\hline $\begin{array}{l}\text { Tintas, vernizes, esmaltes e } \\
\text { lacas }\end{array}$ & 107,27 & 41,67 & 320,17 \\
\hline $\begin{array}{l}\text { Produtos e preparados } \\
\text { químicos diversos }\end{array}$ & 54,47 & 15,78 & 306,89 \\
\hline $\begin{array}{l}\text { Artigos de borracha e } \\
\text { plástico }\end{array}$ & 1193,87 & 395,20 & 8637,93 \\
\hline Cimento & 18,80 & 5,71 & 28,61 \\
\hline $\begin{array}{l}\text { Outros produtos de min- } \\
\text { erais não metálicos }\end{array}$ & 205,42 & 81,53 & 3114,74 \\
\hline $\begin{array}{l}\text { Fabricação de aço e deri- } \\
\text { vados }\end{array}$ & 1490,01 & 489,52 & 2665,08 \\
\hline $\begin{array}{l}\text { Metalurgia de metais não } \\
\text { ferrosos }\end{array}$ & 258,95 & 68,32 & 1019,53 \\
\hline $\begin{array}{l}\text { Produtos de metal (exclu- } \\
\text { sive máquinas e equipa- } \\
\text { mentos) }\end{array}$ & 705,89 & 319,92 & 8631,30 \\
\hline $\begin{array}{l}\text { Máquinas e equipamentos, } \\
\text { inclusive manutenção e } \\
\text { reparos }\end{array}$ & 373,32 & 121,32 & 2551,57 \\
\hline Eletrodomésticos & 2,47 & 0,63 & 9,58 \\
\hline $\begin{array}{l}\text { Máquinas para escritório } \\
\text { e equipamentos de in- } \\
\text { formática }\end{array}$ & 5,61 & 0,93 & 15,08 \\
\hline $\begin{array}{l}\text { Máquinas, aparelhos e } \\
\text { materiais elétricos }\end{array}$ & 575,74 & 183,09 & 3303,70 \\
\hline $\begin{array}{l}\text { Material eletrônico e } \\
\text { equipamentos de comuni- } \\
\text { cações }\end{array}$ & 76,54 & 13,66 & 242,61 \\
\hline $\begin{array}{l}\text { Aparelhos médico-hospital- } \\
\text { ar, de medida e ópticos }\end{array}$ & 26,82 & 15,30 & 241,75 \\
\hline
\end{tabular}




\begin{tabular}{|c|c|c|c|}
\hline Setor & $\begin{array}{l}\text { Impacto na } \\
\text { produção } \\
\text { (R\$ milhões ) }\end{array}$ & $\begin{array}{l}\text { Impacto no PIB } \\
\text { (R\$ milhões ) }\end{array}$ & $\begin{array}{l}\text { Impacto no } \\
\text { emprego } \\
\text { (número de } \\
\text { ocupações) }\end{array}$ \\
\hline $\begin{array}{l}\text { Automóveis, camionetas e } \\
\text { utilitários }\end{array}$ & $11.400,75$ & 1393,07 & $11.858,14$ \\
\hline Caminhões e ônibus & $2.737,26$ & 435,01 & $3.049,75$ \\
\hline $\begin{array}{l}\text { Peças e acessórios para } \\
\text { veículos automotores }\end{array}$ & $4.067,55$ & 1207,62 & $21.503,42$ \\
\hline $\begin{array}{l}\text { Outros equipamentos de } \\
\text { transporte }\end{array}$ & 14,85 & 3,74 & 52,19 \\
\hline $\begin{array}{l}\text { Móveis e produtos das } \\
\text { indústrias diversas }\end{array}$ & 31,65 & 14,05 & 668,51 \\
\hline $\begin{array}{l}\text { Eletricidade e gás, água, } \\
\text { esgoto e limpeza urbana }\end{array}$ & 628,49 & 328,66 & 1565,64 \\
\hline Construção & 155,72 & 82,58 & 3873,69 \\
\hline Comércio & $1.886,50$ & 1376,15 & $62.794,99$ \\
\hline $\begin{array}{l}\text { Transporte, armazenagem } \\
\text { e correio }\end{array}$ & $1.193,37$ & 609,49 & 17983,95 \\
\hline Serviços de informação & 622,69 & 309,91 & 5664,29 \\
\hline $\begin{array}{l}\text { Intermediação financeira e } \\
\text { seguros }\end{array}$ & $1.344,20$ & 901,06 & 4284,75 \\
\hline $\begin{array}{l}\text { Serviços imobiliários e } \\
\text { aluguel }\end{array}$ & 135,97 & 129,12 & 365,19 \\
\hline $\begin{array}{l}\text { Serviços de manutenção e } \\
\text { reparação }\end{array}$ & 58,92 & 45,00 & 3112,72 \\
\hline $\begin{array}{l}\text { Serviços de alojamento e } \\
\text { alimentação }\end{array}$ & 59,80 & 27,60 & 1944,93 \\
\hline $\begin{array}{l}\text { Serviços prestados às } \\
\text { empresas }\end{array}$ & $1.038,51$ & 642,44 & 24400,12 \\
\hline Educação mercantil & 7,48 & 5,02 & 229,50 \\
\hline Saúde mercantil & 15,57 & 8,89 & 299,66 \\
\hline $\begin{array}{l}\text { Serviços prestados às } \\
\text { famílias e associativas }\end{array}$ & 110,99 & 59,55 & 4164,29 \\
\hline Serviços domésticos & 0,00 & 0,00 & 0,00 \\
\hline Educação pública & 1,98 & 1,55 & 54,87 \\
\hline Saúde pública & 0,02 & 0,01 & 0,34 \\
\hline
\end{tabular}




\begin{tabular}{llll}
\hline \multicolumn{1}{c}{ Setor } & $\begin{array}{l}\text { Impacto na } \\
\text { produção } \\
\text { (R\$ milhões ) }\end{array}$ & $\begin{array}{l}\text { Impacto no PIB } \\
\text { (R\$ milhões ) }\end{array}$ & $\begin{array}{l}\text { Impacto no } \\
\text { emprego } \\
\text { (número de } \\
\text { ocupações) }\end{array}$ \\
\hline $\begin{array}{l}\text { Administração pública e } \\
\text { seguridade social }\end{array}$ & 65,28 & 43,57 & 805,16 \\
\hline Impacto da economia total & $32.601,44$ & $9.947,09$ & $211.586,40$ \\
\hline
\end{tabular}

Fonte: Elaboração própria.

Um exercício semelhante pode ser realizado para a arrecadação dos impostos indiretos líquidos de subsídios (IIL). Utilizando as contas nacionais de 2009 do IBGE, obtém-se um coeficiente de IIL de 0.24 para o setor de automóveis. Assim, o aumento na produção desse setor, que ocorreu em resposta à redução do IPI, contribuiu com mais de 2,6 bilhões de reais para a arrecadação do IIL. Ao se analisar as matrizes de 2008 e 2009, a diferença nominal entre esses dois anos, para o IIL, foi de aproximadamente 6,7 bilhões de reais. Evidencia-se, dessa forma, que caso a desoneração do IPI não tivesse ocorrido, a perda em arrecadação dos impostos indiretos teria sido ao menos de 2,6 bilhões de reais superior ao que de fato ocorreu.

Essa evidência apresenta similaridades às obtidas pelo Instituto de Pesquisa Econômica Aplicada (2009). Segundo a pesquisa, a Receita Federal estimou que, de janeiro a junho de 2009, com a desoneração do IPI de automóveis, se deixou de arrecadar $\mathrm{R} \$ 1,817$ bilhão. No entanto, sem a medida, as vendas de veículos e também a receita de outros impostos teriam sido menores. Uma medida mais adequada do custo da desoneração seria o volume total desonerado menos a contribuição positiva que o IPI reduzido gerou sobre a arrecadação dos demais impostos. Apesar da queda real de arrecadação na cadeia automobilística, as estimativas indicam que, sem a desoneração do IPI de automóveis, a arrecadação dos principais tributos federais no primeiro semestre seria menor, em torno de $\mathrm{R} \$$ 1,258 bilhão. Descontando o impacto positivo do IPI reduzido apenas sobre outros tributos federais, chega-se a um custo da redução de alíquotas de $\mathrm{R} \$ 559$ milhões (INSTITUTO DE PESQUISA ECONÔMICA APLICADA, 2009).

Pode-se afirmar que os efeitos da crise na redução do nível de atividade econômica, arrecadação tributária e empregos formais não foram mais intensos em função da políica fiscal contracíclica de redução do IPI para veículos, ou seja, seus efeitos de curto prazo foram positivos. Esse resultado vai de encontro, ao menos em parte, ao defendido por Frankel, Végh e Vuletin (2013) e Brahmbhatt e Canuto (2012), o de que países em desenvolvimento passaram a adotar padrão de política fiscal anticíclica. 


\section{Considerações Finais}

O objetivo deste trabalho é verificar através da metodologia de insumo-produto, dada a importância do setor automobilístico na economia brasileira, os impactos de curto prazo da adoção de política fiscal contracíclica: a de redução das alíquotas do IPI sobre veículos automotores entre 2008 e 2009.

A importância do setor automobilístico na economia brasileira é confirmada por meio dos resultados dos índices de ligação, os quais demonstram que o setor tem intensa participação na economia como demandante de insumo, o que se explica por seus produtos serem voltados à demanda final. Os índices de Hirschman-Rasmussen para trás indicam que os subsetores de automóveis e de caminhões e ônibus apresentam valores acima da média da economia, com 1,27 e 1,25 , respectivamente, sendo que, entre os 56 setores da economia, se posicionam na segunda e terceira posição. Tal classificação se mantém quando analisados os multiplicadores de produção, que são de 2,39 e 2,36, na mesma ordem. Bahia e Domingues (2010) estimaram valores próximos a estes últimos para 2005, sendo respectivamente de 2,23 e 2,47.

No mercado de trabalho brasileiro, a importância do setor é evidenciada através dos multiplicadores de emprego (tipo I), com o setor de automóveis gerando para cada emprego direto criado mais de 15 empregos por toda a economia, e o de caminhões gerando mais de 13 empregos. Dada a hipótese, baseada no estudo do Instituto de Pesquisa Econômica Aplicada (2009), de que a desoneração do IPI gerou um aumento na demanda do setor de $13,4 \%$ durante o ano de 2009 , os resultados da análise de impacto indicam que os efeitos sobre a produção seriam de aumento em mais de $\mathrm{R} \$ 11$ bilhões no subsetor de automóveis e em mais de 2,7 bilhões no de caminhões. Para toda a economia, o resultado seria de um aumento de mais de 32 bilhões na produção e de quase 10 bilhões no PIB.

No mercado de trabalho, a elevação da demanda geraria quase 12 mil postos de trabalho em automóveis e mais de 3 mil em caminhões. Na economia brasileira seriam, então, gerados mais de 211 mil empregos durante o ano, valores bem superiores aos encontrados pelo Instituto de Pesquisa Econômica Aplicada (2009), o qual estimou que a redução do IPI contribuiu para manter entre 50 mil e 60 mil empregos diretos e indiretos na economia brasileira no primeiro semestre de 2009. Ao se analisar os dados da matriz insumo-produto de 2009, verifica-se que houve uma perda efetiva de 2.141 postos de trabalho entre 2008 e 2009. Dessa forma, pode-se afirmar que, caso não tivesse ocorrido a desoneração, as perdas teriam sido mais elevadas.

Resumindo, os resultados apresentados levam a uma única e abrangente predição: as respostas de curto prazo à política fiscal contracíclica, de redução de alíquotas de impostos, operaram através da demanda agregada, ou seja, trata-se 
de uma resposta do tipo keynesiana, estabilizadora, que contribuiu para amenizar os impactos negativos da crise financeira na economia brasileira. Considerando esta análise de curto prazo aqui desenvolvida, uma possibilidade inevitável para futuras pesquisas inclui uma análise de longo prazo e, consequentemente, as implicações de uma política fiscal contracíclica ao desenvolvimento econômico.

\section{Referências}

ASSOCIAÇÃO NACIONAL DOS FABRICANTES DE VEÍCULOS AUTOMOTORES. Anuário da indústria automobilística brasileira. São Paulo, 2011. Disponível em: <http://www.anfavea. com.br/anuario.html>. Acesso em: 5 maio 2012.

ASSOCIAÇÃO NACIONAL DOS FABRICANTES DE VEÍCULOS AUTOMOTORES. Estatísticas. 2009/2010. Disponível em: <http://www.anfavea.com.br/tabelas.html>. Acesso em: 7 maio 2012.

ASSUNÇÃO, M. C. Incentivos fiscais em tempos de crise: impactos econômicos e reflexos financeiros. Revista da PGFN, v. 1, n. 1, p. 99-121, 2011.

BAHIA, L. D.; DOMINGUES, E. P. Estrutura de inovações na indústria automobilística brasileira. Brasília, DF: Ipea, fev. 2010. (Texto para Discussão, n. 1472).

BLANCO, F.; HERRERA, S. The quality of fiscal adjustment and the long-run growth impact of fiscal policy in Brazil. Washington: World Bank, 2006. (Policy Research Working Paper, n. 4004).

BRAHMBHATT, M.; CANUTO, O. Fiscal policy for growth and development: poverty reduction and economic management. Economic Premise, World Bank, n. 91, p. 1-7, Oct. 2012.

BRASIL. Ministério da Fazenda. Economia brasileira em perspectiva. Edição especial. Brasília, DF: MF, 2010. Disponível em: < http://www.fazenda.gov.br/divulgacao/publicacoes/ economia-brasileira-em-perspectiva/economia_brasileira_em_perspectiva_pt_ed_ especial_2010.pdf >. Acesso em: 25 maio 2012.

. Presidência da República. Decreto $n^{0}$ 6.687, de 11 de dezembro de 2008. Altera a Tabela de Incidência do Imposto sobre Produtos Industrializados - TIPI, aprovada pelo Decreto no 6.006, de 28 de dezembro de 2006, e dá outras providências. Disponível em: <http://www.planalto.gov.br/ccivil_03/_Ato2007-2010/2008/Decreto/D6687.htm>. Acesso em: 10 maio 2012.

Presidência da República. Decreto $n^{\circ}$ 6.743, de 15 de janeiro de 2009. Dá nova redação ao art. 20 do Decreto no 6.687, de 11 de dezembro de 2008, que altera a Tabela de Incidência do Imposto sobre Produtos Industrializados - TIPI, aprovada pelo Decreto no 6.006, de 28 de dezembro de 2006. Disponível em: < http://www.planalto.gov.br/ccivil_03/_ Ato2007-2010/2009/Decreto/D6743.htm>. Acesso em: 10 maio 2012.

CECCHINI, K. et al. Brazilian automotive industry in the nineties. Latin American Business Review, v. 7, n. 3-4, p. 121-150, July/Dec. 2007. 
COSTA, C. C.; GUILHOTO, J. J. M. O papel da tributação diferenciada dos combustíveis no desenvolvimento econômico do estado de São Paulo. Revista de Economia Aplicada, v. 15, n. 3, p. 369-390, jul./set. 2011.

FRANKEL, J. A.; VEGH, C. A.; VULETIN, G. On graduation from fiscal procyclicality. Journal of Development Economics, v. 100, n. 1, p. 32-47, Jan. 2013.

GAVIN, M.; PEROTTI, R. Fiscal policy in Latin America. In: BERNANKE, B.; ROTEMBERG, J. (Ed.). NBER Macroeconomics Annual. Cambridge, MA: MIT Press, 1997.

GEMMELL, N.; MISCH, F.; MORENO-DODSON, B. Public spending and long: run growth in practice: concepts, tools, and evidence (chapter 2). In: MORENO-DODSON, B. (Ed.). Is fiscal policy the answer? A developing country perspective. Washington, DC: World Bank, 2012.

GUILHOTO, J. J. M. Análise de insumo-produto: teoria e fundamentos. Livro em elaboração. Departamento de Economia. FEA-USP. Versão Revisada. 2011. Disponível em: < http:// mpra.ub.uni-muenchen.de/32566/> . Acesso em: 17 jun. 2012.

GUILHOTO, J. J. M.; POLENSKE, K. R.; LIU, H. China and Brazil productive structure and economic growth compared: 1980's to 2000's. Germany: University Library of Munich, nov. 2010. (MPRA Working Paper, n. 30123).

GUILHOTO, J. J. M.; SESSO FILHO, U. Estimação da matriz insumo-produto a partir de dados preliminares das contas nacionais. Economia Aplicada, v. 9, n. 2, p. 277-299, abr./jun. 2005 .

. Estimação da matriz insumo-produto utilizando dados preliminares das contas nacionais: aplicação e análise de indicadores econômicos para o Brasil em 2005. Economia e Tecnologia, v. 23, n. 6, p. 53-62, out./dez. 2010.

GUILHOTO, J. J. M; SONIS, M.; HEWINGS, G. J. D. Linkages and multipliers in a multiregional framework: integration of alternative approaches. Australasian Journal of Regional Studies, v. 11, n. 1, p. 75-89, Jan. 2005.

HIRSCHMAN, A. O. The strategy of economic development. New Haven: Yale University, 1958.

IBGE. Pesquisa industrial mensal: produção física Brasil. 2008. Disponível em: <http://www. ibge.gov.br/home/estatistica/indicadores/industria/pimpfbr/default.shtm > . Acesso em: 14 fev. 2013.

Sala de imprensa. Em 2010, PIB varia 7,5\% e fica em R\$ 3,675 trilhões. 2011. Disponível em: <http://saladeimprensa.ibge.gov.br/pt/noticias?view=noticiaEid = 1 \&busca $=1$ Eidnoticia $=1830>$. Acesso em: 14 fev. 2013 .

INSTITUTO DE PESQUISA ECONÔMICA APLICADA. Nota técnica: impactos da redução do Imposto sobre Produtos Industrializados (IPI) de automóveis. 2009. Disponível em: <http:// www.ipea.gov.br>. Acesso em: 01 jun. 2012.

KAMINSKI, G.; REINHART, C.; VEGH, C. When it rains it pours: procyclical capital flows and macroeconomic policies. Cambridge, MA: The National Bureau of Economic Research, Sept. 2004. (NBER Working Paper, n. 10780). 
LAPLANE, M. F.; SARTI, F. The Brazilian automobile industry in the nineties. In: International Colloquium of Gerpisa, 4., 1996, Paris. Anais... Paris: Gerpisa, 1996. Disponivel em: <http:// gerpisa.org/ancien-gerpisa/actes/20/article3.html>. Acesso em: 27 fev. 2013.

MELLO, L.; MOCCERO, D. Brazil's fiscal stance during 1995-2005: the effect of indebtedness on fiscal policy over the business cycle. OECD Economics Department, June 2006. (Working Paper, n. 485.).

MILLER, R. E.; BLAIR, P. D. Input-output analysis: foundations and extensions. Englewood Cliffs: Prentice-Hall, 2009.

MORAES, R. A.; SILVEIRA, J. A. G. Elasticidade-preço e elasticidade-renda da demanda na indústria automobilística brasileira: uma análise da última década para os veículos populares. In: SEMINÁRIOS EM ADMINISTRAÇÃO DA FEA-USP, 8., 2005, São Paulo. Anais... São Paulo: USP, 2005. p. 1-15.

NEGRI, F. et al. Determinantes da acumulação de conhecimento para inovação nos setores industriais no Brasil: setor automotivo. 2008. Disponível em: <http:/www.abdi.com.br/ Estudo/Relatório\%20Automotivo.pdf>. Acesso em: 17 fev. 2013.

NEGRI, J. A. Elasticidade-renda e elasticidade-preço da demanda de automóveis no Brasil. Brasília: IPEA, abr. 1998. (Texto para Discussão, n. 558).

RASMUSSEN, P. N. Studies in inter-sectoral relations. Amsterdam: North Holland, 1956.

ROCHA, F. Política fiscal através do ciclo e operação dos estabilizadores fiscais. Revista de Economia, Brasília, v. 10, n. 2, p. 483-499, set./dez. 2009.

SANTOS, A. M. M. M.; BURITY, P. O complexo automotivo. In: SÃO PAULO, E. M.; KALACHE FILHO, J. (Org.). BNDES 50 anos: histórias setoriais. Rio de Janeiro: BNDES, 2002. Disponível em: <http://www.bndes.gov.br/SiteBNDES/export/sites/default/bndes_pt/ Galerias/Arquivos/conhecimento/livro_setorial/setorial06.pdf> . Acesso em: 11 mar. 2013.

SICSÚ, J. A Economia brasileira durante a crise: indicadores de performance e perspectivas. In: BISPO, C. R. et al. (Org.). Crise financeira mundial: impactos sociais e no mercado de trabalho. Brasília, DF: Associação Nacional dos Auditores Fiscais da Receita Federal do Brasil, 2009. Disponível em: <http://dowbor.org/blog/wp-content/uploads/2012/06/102859970Crise-Financeira-Mundial.pdf> Acesso em: 14 fev. 2013.

TAKASAGO, M. et al. O potencial criador de emprego e renda do turismo no Brasil. Pesquisa e Planejamento Econômico, v. 40, n. 3, p. 431-460, dez. 2010.

TALVI, E.; VEGH, C. Tax base variability and procyclicality of fiscal policy. Journal of Development Economics, v. 78, n. 1, p. 156-190, Oct. 2005.

UNIVERSIDADE DE SÃO PAULO. Núcleo de Economia Regional e Urbana. Sistema de Matrizes de Insumo-Produto, Brasil (1995-2009). 2012. Disponível em: <http://www.usp.br/ nereus/?fontes $=$ dados-matrizes $>$. Acesso em: 02 jun. 2012.

Recebido em: 23/11/2013. Aceito em: 19/08/2014. 